\title{
A case of anti-LGl-1 encephalitis presented as acute psychosis
}

\author{
Mohammed Reyazuddin", Faisal Shaan and S. A. Azmi
}

\begin{abstract}
Anti-leucine-rich glioma inactivated protein-1 (LGI-1) encephalitis is a rare autoimmune disease with a varied neuropsychiatric clinical manifestation and have potential for reversal with immunotherapy. Early identification and treatment are therefore of paramount importance. We present the case of a 43-year-old man admitted for acute psychosis with facio-brachial dystonic seizures not responding to anti-epileptic drugs (AEDs). His symptoms started approximately 5 months prior admission to the hospital and associated with progressive cognitive impairment (particularly verbal and visio-spatial domains) followed by altered behavior, irrelevant talk, and disturbance in daily activities of living and facio-brachial dystonic seizures. There was history of allergic reaction to valproate, carbamazepine and levetiracetam, and serum sample tested strongly positive for LGl-1 (leucine rich glioma inactivated-1) antibodies. He was treated with injection methylprednisolone (1 gm intravenous) brief pulse therapy for 7 days and then underwent four sessions of plasma exchange followed by oral steroids and immunosuppressant therapy. Treatment was successful and patient returned to his previous baseline functioning but patient develops steroid induced hypomania and diabetes mellitus in the due course of time. Patient was discharged after successful resolution of symptoms. Patient did not come up for follow-up. He was contacted telephonically and we get to know that he relapsed after 2 weeks and consulted at higher center where he died while on treatment. Prognosis of anti-LGl-1 encephalitis is usually good but our patient died.
\end{abstract}

Keywords: LGI-1 encephalitis, Acute psychosis

\section{Introduction}

Limbic encephalitis (LE) is a prototype of autoimmune encephalitis which is a rare neurological disorder. Initially, family members notice seizures and/or report that their relative becomes forgetful, confused, drowsy, and withdrawn. Seizures occur in almost all cases but can look very subtle. These may take the form of brief jerks of the face and arm (termed facio-brachial seizures)this diagnostic sign is highly suggestive of LGI-1antibodies. Patient can also present with other neuropsychiatric manifestations like odd behavior, cognitive impairment, or psychosis-like features [1]. Various autoimmune encephalitis have been described, and each of them was linked to the presence of specific autoantibodies directed against synaptic and neuronal cell surface

* Correspondence: reyaz39@gmail.com

Department of Psychiatry, J.N Medical College, AMU, Aligarh, UP, India antigens. The main targets appear to be N-methyl-d-aspartate receptor (NMDAR), $\alpha$-amino-3-hydroxy-5-methyl4isoxazolepropion acid receptor (AMPAR), leucine-rich glioma inactivated 1 (LGI-1), contactin-associated protein-like 2 (Caspr2), glutamate decarboxylase (GAD), or gammaaminobutyric acid type $B$ receptor (GABABR), but a significant number of autoimmune encephalitis are due to rarer or unidentified targets $[2,3]$. Only few case series and reports from India have been published [4].

\section{Case report}

Patient Mr. R, a 43-years-old illiterate, married, male, and belonging to lower SES presented with altered behavior, visual hallucinations, jerky movements of face and arm, cognitive decline, ataxic gait, and multiple falls associated with physical injuries. His symptoms started approximately 5 months prior admission to our hospital. Facio-brachial dystonic seizures with fluctuating mental

\section{Springer Open}

( ) The Author(s). 2020 Open Access This article is licensed under a Creative Commons Attribution 4.0 International License, which permits use, sharing, adaptation, distribution and reproduction in any medium or format, as long as you give appropriate credit to the original author(s) and the source, provide a link to the Creative Commons licence, and indicate if changes were made. The images or other third party material in this article are included in the article's Creative Commons licence, unless indicated otherwise in a credit line to the material. If material is not included in the article's Creative Commons licence and your intended use is not permitted by statutory regulation or exceeds the permitted use, you will need to obtain permission directly from the copyright holder. To view a copy of this licence, visit http://creativecommons.org/licenses/by/4.0/. 
status and progressive cognitive impairment (particularly verbal and visiospatial domains) dominated the clinical picture.

Patient was diagnosed as a case of myoclonus at an outside hospital and anti-epileptics were prescribed. Despite strict adherence to AEDs regimen, there was deterioration in patient's symptomatology and he also developed allergic reaction to AEDs (carbamazepine and levetiracetam) resulting in treatment discontinuation.

On admission, he had regular pulse, was afebrile, and found to be hypertensive. Pupils were normal and fundus examination revealed clear media and pink optic disk with clear margins. Facio-brachial dystonic seizures with impaired awareness occurred at frequency of 40-50 episodes/h. Attention was arousable, but he had difficulty concentrating; he was not oriented to time, place, and person and scored 15/30 on MMSE.

His gait was mildly ataxic with patient often requiring assistance from family members. Normal muscle tone and bulk with elicitable deep tendon reflexes was noted in all four limbs with bilaterally flexor plantar. He had no other neurological deficits, and the remainder of his examination was unremarkable.

Blood counts and standard serum chemistry were within normal limits. Serum sample tested strongly positive for LGI-1 (leucine rich glioma inactivated-1) antibodies by immunofluorescence method at NIMHANS, Bangalore, India (one of the few government centers having this facility at an affordable cost). X-ray of left wrist (anteroposterior and lateral) revealed fractured distal end of radius. MRI brain, EEG, and CSF analysis were otherwise unremarkable. Paraneoplastic work up to rule out any underlying malignancy was unyielding.

Patient is managed at our center as he is very poor and refused to go any other dedicated center of neurosciences.

Patient was treated with Injection methylprednisolone (1 gm intravenous) brief pulse therapy for 7 days and then underwent four sessions of plasma exchange. Patient responded to the treatment, returned to his previous baseline function, and was shifted to oral steroid and immunosuppressant, and AEDs were stopped gradually.

Patient also developed polyphagia, polyuria, and polydipsia with low platelet counts following plasma exchange and steroid Pulse therapy. HbA1c came out to be $7 \%$ with random blood sugar in the range $300-400 \mathrm{mg} / \mathrm{dl}$. Patient also developed sleep disturbance (insomnia), had increased self-esteem, and became more talkative than usual following oral steroid and immunosuppressant therapy. A diagnosis of comorbid treatment induced diabetes mellitus and treatment induced hypomania was made and tablet haloperidol $5 \mathrm{mg} \mathrm{BD}$ with injectable $\mathrm{S} / \mathrm{C}$ insulin advised after endocrinology consultation.

Patient was discharged with complete resolution of symptoms. Patient was followed up at 1 month postdischarge through telephone consultation when family members reported relapse of symptoms and patients' demise about a week back.

\section{Discussion}

LGI-1 is a protein secreted by hippocampal neurons largely associated with epilepsy. In some cases of encephalitis, patients produce autoantibodies directed against LGI-1. There is still not a lot of data concerning LGI-1 autoantibodies as it was first assimilated to antibodies raised against the voltage-gated potassium channel. Indeed, antibodies against voltage-gated potassium channels were first described in neuromyotonia, then in Morvan's syndrome and finally in limbic encephalitis. More recently, studies demonstrated that this entity gathered various encephalitis due to distinct antibodies targeting LGI-1, Caspr2, and contactin $2[5,6]$.

Identification of these antigens helped to clarify the apparent diversity of symptoms attributed to voltagegated potassium channel antibodies. While anti-LGI-1 antibodies are preferentially associated with classical limbic encephalitis, anti-Capsr2 antibodies are associated with Morvan's syndrome, neuromyotonia, and sometimes with neuropathies or limbic encephalitis $[5,6]$.

Corticosteroids, intravenous immunoglobulin, and plasma exchange are most frequently used as therapeutic options. Other immune-suppressive agents like cyclophosphamide and rituximab can also be utilized as a therapeutic option [7, 8]. A study conducted by Saidha et al. [9] also shows promising results with decrease in seizure frequency and improvement in behavior memory testing in these patients with the use of mycophenolate mofetil. Development of these therapeutic options highlights the need for early detection and aggressive management for patients with autoimmune limbic encephalitis. However, in cases where evidence of tumor is found, efforts to remove it or treat it by means of surgery, radiotherapy, or chemotherapy can be sought after. If this disease process is considered early, diagnosed promptly, and treated appropriately, it can be reversed and the patient can be restored to their premorbid state. Prognosis of autoimmune encephalitis is usually good, and mortality of the patient in this case is unexplained. Detection and management of autoimmune encephalitis is very challenging in developing countries like India due to lack of resources, poor affordability, and presence of only few dedicated centers.

\section{Acknowledgements}

NIL

\section{Authors' contributions}

MR wrote, interpreted, and analyzed the manuscript. FS contributed to the data collection and workup of the case. SA contributed to the supervision and diagnosis of the case. All authors read and approved the final manuscript. 


\section{Funding}

$\mathrm{NIL}$

\section{Availability of data and materials}

The datasets used and/or analyzed during the current study are available from the corresponding author on reasonable request.

\section{Ethics approval and consent to participate}

The consent was taken.

\section{Consent for publication}

The patient had signed an informed consent to allow his data to be published.

\section{Competing interests}

The authors declare that they have no competing interests.

Received: 13 March 2020 Accepted: 11 June 2020

Published online: 29 June 2020

\section{References}

1. Kristin J. Somers, Vanda A. Lennon, James R. Rundell, Sean J. Pittock, Daniel A. Drubach, Max R. Trenerry, Daniel H. Lachance, Christopher J. Klein, Paula A. Aston, Andrew McKeon, J Neuropsychiatry Clin Neurosci 23:4, Fall 2011.

2. Van Coevorden-Hameete MH, de Graaff E, Titulaer MJ, Hoogenraad CC, Sillevis Smitt PAE. Molecular and cellular mechanisms underlying antineuronal antibody mediated disorders of the central nervous system. Autoimmun Rev. 2014;13(3):299-312.

3. Chefdeville A, Honnorat J, Hampe CS, Desestret V. Neuronal CNS syndromes likely mediated by autoantibodies. Eur J Neurosci. 2016;43:1532-52.

4. Jacob S. Autoimmune encephalitis - The evolving spectrum: An Indian case series. Neurol India. 2015;63:647-9.

5. Irani SR, Alexander S, Waters $P$, et al. Antibodies to Kv1 potassium channelcomplex proteins leucine-rich, glioma inactivated 1 protein and contactinassociated protein-2 in limbic encephalitis, Morvan's syndrome and acquired neuromyotonia. Brain. 2010;133(9):2734-48.

6. Joubert B, Saint-Martin M, Noraz N, et al. Characterization of a subtype of autoimmune encephalitis with anti-contactin-associated protein-like 2 antibodies in the cerebrospinal fluid, prominent limbic symptoms, and seizures. JAMA Neurol. 2016;73(9):1115-24.

7. Bataller L, Kleopa KA, Wu GF, Rossi JE, Rosenfeld MR, et al. Autoimmune limbic encephalitis in 39 patients: immunophenotypes and outcomes. J Neurol Neurosurg Psychiatry. 2007;78:381-5.

8. Dalmau J, Gleichman AJ, Hughes EG, Rossi JE, Peng X, et al. Anti-NMDAreceptor encephalitis: case series and analysis of the effects of antibodies. Lancet Neurol. 2008;7:1091-8.

9. Saidha S, Murphy S, Ronayne A, McCarthy P, Hennessy MJ, et al. Treatment of anti-glutamic acid decarboxylase antibodyassociated limbic encephalitis with mycophenolate mofetil. J Neurol. 2010;257:1035-8.

\section{Publisher's Note}

Springer Nature remains neutral with regard to jurisdictional claims in published maps and institutional affiliations.

\section{Submit your manuscript to a SpringerOpen ${ }^{\odot}$ journal and benefit from:}

- Convenient online submission

Rigorous peer review

- Open access: articles freely available online

High visibility within the field

- Retaining the copyright to your article 